\title{
LANGUAGE MEANS OF REPRESENTING NUMINOUS EMOTIONS (BASED ON THE MATERIAL OF THE ENGLISH BIBLE TEXT)
}

\author{
Sergey M. Pashkov \\ Saint Petersburg State Pedagogical University (Volkhov Branch), Volkhov, Russia
}

\begin{abstract}
The research relevance consists in studying the specific sphere of human life that is poorly studied in linguistics - expression of emotions experienced with respect to the God. We specify substantive content of the term 'numinousness' and carry out its analysis from the viewpoint of emotion studies on the material of King James Bible. The necessity of differentiating emotive meanings verbalized in the text of the Bible into numinous (always positive) and anuminous (positive/negative) has been pointed out. As a result, three groups of lexemes representing numinous emotions have been classified: 1) an emotion of creature-consciousness; 2) an emotional cluster 'Mysterium tremendum'(awe, fear); 3) an emotional cluster 'Mysterium fascinans' (fascination, wonder, bliss, happiness, joy). The research shows that the analyzed lexemes are characterized with either positive occasional (the first and the second groups) or positive usual (the third group) evaluative orientation. It is shown that the reversion of an evaluative component in the language means representing numinous emotions is recurrent. This change is considered as a peculiarity of emotivity category representation in the biblical text. The proposed linguistic analysis of numinous emotions makes it possible to broaden scholarly knowledge of linguistic representation of inner self in the biblical text and to project a new prospect of further research in representing the category of emotivity in sacral texts in general.

Key words: The Bible, biblical text, numinous emotion, diffusion of emotions, emotivity, emotive and evaluative sequence, context, lexis.
\end{abstract}

Citation. Pashkov S.M. Language Means of Representing Numinous Emotions (Based on the Material of the English Bible Text). Vestnik Volgogradskogo gosudarstvennogo universiteta. Seriya 2, Yazykoznanie [Science Journal of Volgograd State University. Linguistics], 2018, vol. 17, no. 1, pp. 52-62. (in Russian). DOI: https:// doi.org/10.15688/jvolsu2.2018.1.6

\section{ЯЗЫКОВЫЕ СРЕДСТВА РЕПРЕЗЕНТАЦИИ НУМИНОЗНЫХ ЭМОЦИЙ (НА МАТЕРИАЛЕ АНГЛОЯЗЫЧНОГО ТЕКСТА БИБЛИИ)}

\author{
Сергей Михайлович Пашков \\ Санкт-Петербургский государственный педагогический университет им. А.И. Герцена \\ (Волховский филиал), г. Волхов, Россия
}

\begin{abstract}
Аннотация. Актуальность статьи определяется обращением к мало изученной в лингвистике специфической сфере человеческой жизни - проявлению эмоций, испытываемых человеком по отношению к Богу. Автор уточняет содержательное наполнение понятия нуминозности и рассматривает его в эмотиологическом преломлении на материале текста Библии короля Якова. Постулируется необходимость деления эмотивсмыслов, эксплицируемых в тексте Библии, на нуминозные (всегда положительные) и ануминозные ( тирующие нуминозные переживания: 1) эмоцию тварности; 2) эмоциональный кластер «Mysterium \% tremendum» (благоговение, страх); 3) эмоциональный кластер «Mysterium fascinans» (очарование, удивление, блаженство, счастье, радость). Установлена положительная окказиональная (первая и вторая группы) и Є узуальная (третья группа) оценочная направленность рассмотренных лексем. Показано, что реверсия оце() ночного знака у лексем, репрезентирующих нуминозные эмоции, носит рекуррентный характер и рассмат-
\end{abstract}


ривается автором как проявление специфики репрезентации категории эмотивности в библейском тексте. Полученные результаты позволили расширить научные представления об особенностях языковой репрезентации внутреннего «Я» в библейском тексте и наметить перспективу дальнейшего изучения особенностей репрезентации категории эмотивности в сакральных текстах в целом.

Ключевые слова: Библия, библейский текст, нуминозная эмоция, диффузность эмоций, эмотивность, эмоционально-оценочный ряд, контекст, лексика.

Цитирование. Пашков С.М. Языковые средства репрезентации нуминозных эмоций (на материале англоязычного текста Библии) // Вестник Волгоградского государственного университета. Серия 2, Языкознание. -2018. - Т. 17, № 1. - С. 52-62. - DOI: https://doi.org/10.15688/jvolsu2.2018.1.6

\section{Введение}

Пристальное внимание современной лингвистики к «моделированию внутреннего человека» (Н.Д. Арутюнова) свидетельствует о сложности эмоциональных процессов и недостаточной разработанности актуальной проблемы «эмоции в языке». В частности, одной из важных исследовательских задач признается выявление специфики репрезентации категории эмотивности в текстах разной типологической отнесенности [Филимонова, 2016]. Думается, что в плане исследования языковых средств, репрезентирующих эмоции человека, библейский текст представляет значительный научный интерес. Во-первых, peaлизация антропологической программы изучения языка, актуальной для современной науки, предполагает, помимо прочего, рассмотрение человека не имманентно, в его самодостаточном бытии, а как Homo religiosus (человека религиозного) [Постовалова, 2014, c. 128-129]. Во-вторых, религия играла и играет «выдающуюся роль в судьбах языков» [Мечковская, 1998, с. 3]. В-третьих, эмотивная функция в религиозной коммуникации характеризуется как одна из ведущих [Бобырева, 2015, с. 53]. В-четвертых, подавляющее количество исследований в области эмотивности языка и речи посвящено языковой репрезентации «междучеловеческих чувств» (М.М. Бахтин), то есть чувств, связывающих человека с другими людьми, однако человек может испытывать эмоции, выходящие за пределы координаты «человек - человек», например эмоции по отношению к Богу [Бахтин, 2002, c. 374] (ср. «религиозная эмоция» у А.А. УХтомского [Ухтомский, 1996, с. 368]). Среди «религиозных эмоций», репрезентируемых, в частности, в библейских текстах, наиболее значимыми являются «нуминозные эмоции» ${ }^{1}$.

\section{Понятие нуминозной эмоции}

Нуминозное (от лат. nитеп - божественное волеизъявление, божество, знак божественного могущества) обозначает данности религиозного опыта, сопряженные с сильным переживанием устрашающего и таинственного присутствия Бога. В религиозном опыте Бог открывает себя как numen, и происходит встреча нуминозного объекта с чувством нуминозного [Энциклопедия..., 2009, с. 613].

Содержательное наполнение понятия нуминозного осмысляется в классическом труде немецкого теолога и философа Р. Отто «Священное» [Энциклопедия..., 2009, с. 613]. Нуминозное переживание - сложная формация, состоящая из нескольких эмоций, или, как пишет философ, «моментов» нуминозного (cp. понимание тревоги как комбинацию нескольких дискретных эмоций у К.Э. Изарда [Изард, 2011 , с. 325]). Охарактеризуем наиболее важные из них.

Основная эмоция в составе нуминозного переживания определяется как «чувство тварности» ${ }^{2}$, то есть «чувство твари, которая тонет в собственном ничто и склоняется перед тем, что выше всякого творения» [Отто, 2008$, c. 18$]$. Данная эмоция возникает в момент сильной религиозной возбужденности, когда присутствие Бога переживается hic et nunc. Так, тварность проявляется в ощущениях «падшести», «ничтожности», в «девальвации меня самого». Однако эта эмоция возникает у религиозного человека не от нарушения нравственного закона, хотя это не исключается, а скорее от «безусловной нечестивости» [Отто, 2008, с. 19, 91, 92] (курсив наш. - С. П.).

Нуминозная эмоция тварности свидетельствует о смирении человека перед святостью и онтологическим превосходством 
Бога [Отто, 2008, с. 33], а смирение признается одной из главных добродетелей в христианстве. Как следствие, эмоция тварности, в том числе и ее художественный аналог, является положительной. Посягательство человека на равенство с Творцом, описываемое в Библии, наказывается изгнанием прародителей из рая.

Эмоция тварности обусловливает формирование эмоционального кластера «Mysterium tremendum» («тайна, повергающая в трепет»), в котором концентрируется нуминозное переживание [Энциклопедия..., 2009, с. 614]. Numen может повергать в ужас и дрожь, приводить к странному волнению, смиренному содроганию и онемению твари перед тем, что «в несказанной тайне возвышается над всяким творением» [Отто, 2008, с. 22] (курсив наш. - С. П.).

Содержательное наполнение понятия страха в библейской традиции шире, чем то, которое ему приписывается в психологии. Под Страхом Божиим (нуминозный страх) понимается благоговение смешанное с трепетом (ББС, 2005, с. 1208), благоговение же, сошлемся на М.М. Бахтина, коренится в «таинственной области, уходящей в последние глубинные первоосновы человеческой жизни». Благоговение, по мнению мыслителя, сопровождается «онемением», которое свидетельствует о достоинстве человека [Бахтин, 2002, с. 376] (курсив наш. - С. П.). Разумеется, в Библии описывается «ануминозный» страх, то есть страх человека перед опасностью, наказанием за преступления, однако он не является основным (ББС, с. 1208). Думается, эту разновидность страха имеет в виду Е.В. Бобырева, когда делит эмоциональное поле религиозного дискурса на два блока: блок положительно окрашенных эмоций и блок эмоций, окрашенных отрицательно, относя ко второму блоку, помимо прочего, страх [Бобырева, 2015, c. 53].

Специфичность эмоционального кластеpa «Mysterium tremendum» проявляется в том, что Бог не только ужасает, но и особым образом притягивает, очаровывает, изумляет, сообщает твари блаженство. Испытывая страх перед Творцом, «тварь в то же время всегда тянется к нему, чтобы как-то с ним соединиться» [Отто, 2008, с. 59]. Этот эмоциональ- ный кластер (очарование, удивление, блаженство, счастье, радость) в составе нуминозного переживания Р. Отто определяет термином «Mysterium fascinans» («тайна очаровывающая»). Важным представляется то, что эта особенность нуминозных эмоций (Бог одновременно ужасает и очаровывает человека) репрезентируется в сакральных текстах и является их важнейшим элементом. Так, И.Т. Касавин пишет об ощущениях «восторженного ужаса» и «ошеломленного поклонения», репрезентируемых в этих текстах [Касавин, 1998, с. 165] (курсив наш. - С. П.).

Исходя из приведенного понимания нуминозных эмоций, представляется оправданным выделение в эмотивном пространстве библейского текста нуминозных (всегда положительных) и ануминозных (положительных / отрицательных) эмотивных смыслов.

Категория эмотивности, как показано в работах О.Е. Филимоновой, имеет особенности репрезентации в текстах разных типов [Филимонова, 2007; 2016]. Думается, что применительно к тексту Библии этот тезис находит свое обоснование в сфере репрезентации сложных нуминозных переживаний.

Лингвистическое описание текста детерминировано двумя важными факторами: «сложностью самого текста», включенного в историко-культурный контекст (ср. текст Библии), и «сложностью человека», порождающего, воспринимающего, интерпретирующего и / или исследующего текст [Щирова, 2013, с. 37] (курсив И.А. Щировой. - С. П.). При анализе семантических категорий, в том числе категории эмотивности, важнейшее значение приобретает принцип онтологизма, заключающийся в признании детерминации рассматриваемых категорий восприятием объективной действительности [Бондарко, 1987, с. 31].

С учетом онтологии нуминозных эмоций (они вызваны Божественным присутствием и имеют положительную направленность) нами анализируются:

- языковые репрезентанты нуминозной эмоции тварности;

- языковые репрезентанты эмоционального кластера «Mysterium tremendum» (благоговение, страх);

- языковые репрезентанты эмоционального кластера «Mysterium fascinans» 
(очарование, удивление, блаженство, счастье, радость).

Выделенные группы языковых средств исследуются с применением разработанного лингвистикой эмоций метода эмотивного анализа, который заключается в выделении названных, описанных, выраженных эмоций и определении оценочного знака эмотивов [Шаховский, 2009].

Поскольку нуминозные эмоции возникают в момент сильной религиозной возбужденности (Р. Отто), для лингвистического анализа отобраны фрагменты, в которых изображаются «наиболее религиозные» библейские персонажи, играющие важную роль в библейской истории (Авраам, Давид, Неемия, Соломон, Иов, Исайя, Петр). Объем анализируемых в статье микроконтекстов определяется их достаточностью для адекватной интерпретации эмотивно-прагматического содержания языковых средств репрезентации нуминозных эмоций. Источником для отбора материала послужила Библия короля Якова (1611 г.) ${ }^{3}$.

\section{Репрезентация эмоции тварности}

В тексте Библии, описывающем мировой процесс как открытый диалог Творца и творения [Аверинцев, 2006, с. 408], были выделены следующие языковые средства, репрезентирующие нуминозную эмоцию тварности персонажа: а) лексемы с конкретной семантикой, характеризующие тварность человека (ashes, dust, flesh, creature, clay); б) лексемы с абстрактной семантикой, характеризующие нечестивость и порочность человека (filthy, vile, iniquity, unclean, vanity, nothing). В контексте Библии в семантике этих единиц актуализируется потенциальная / наведенная эмосема 'унижение' со знаком «+» (ср. слова Христа «кто возвышает себя, тот унижен будет, а кто унижает себя, тот возвысится»).

(1) And the LORD said, If I find in Sodom fifty righteous within the city, then I will spare all the place for their sakes. And Abraham answered and said, Behold now, I have taken upon me to speak unto the Lord, which am but dust and ashes (Genesis, 18: 26-27).

В микроконтексте (1) описывается важный для библейской истории диалог Авраама с Богом, в котором патриарх умоляет о поми- ловании Содома и Гоморры. Лексическая единица (далее - ЛЕ) the Lord, номинирующая Бога, а также глаголы говорения (said, answered, speak) свидетельствуют об их беседе. Этот контакт с Творцом вызывает у Авраама нуминозную эмоцию тварности, репрезентируемую существительными с конкретной семантикой dust и ashes, содержащими в своем значении сему 'вещество'. Ср.:

- dust: «fine particles of matter (as of earth)»;

- $\operatorname{ash}(e s)$ : «the solid residue left when combustible material is thoroughly burned or is oxidized by chemical means» $(\mathrm{M}-\mathrm{W})$ (здесь и далее в словарных толкованиях курсив наш. - С. П.).

Праведный Авраам идентифицирует себя с прахом и осознает свою онтологическую несопоставимость с Богом. Основанием для такой интерпретации образа можно рассматривать и то, что ЛЕ dust и ashes актуализируют в тексте, помимо вышеуказанного, еще один компонент значения - сему 'унижение'

- ash(es): «something that symbolizes grief, repentance, or humiliation»;

- dust: «a state of humiliation» (M-W).

Повтор существительных с семой 'унижение' акцентирует безусловную нечестивость Авраама, несмотря на его праведность и богобоязненность.

(2) What is man, that he should be clean? and he which is born of a woman, that he should be righteous? Behold, he putteth no trust in his saints; yea, the heavens are not clean in his sight. How much more abominable and filthy is man, which drinketh iniquity like water? (Job, 15: 14-16).

(3) Then Job answered the LORD, and said, Behold, I am vile; what shall I answer thee? I will lay mine hand upon my mouth (Job, 40: 3-4).

(4) I have heard of thee by the hearing of the ear: but now mine eye seeth thee. Wherefore I abhor myself, and repent in dust and ashes (Job, 42: 5-6).

В микроконтекстах (2), (3), (4) приводится диалог Иова с Богом. Глаголы говорения (answered, said) и восприятия (heard, seeth), а также местоимения первого и второго лица $(I$, thee) индицируют позиции участников данного коммуникативного акта и маркируют встречу праведника с Творцом. Эмоция тварности выражается ЛЕ с конкретной (dust, 
ashes) и абстрактной (filthy, vile, iniquity) ceмантикой. В тексте актуализируется свойственная ЛЕ filthy, vile и iniquity сема 'нечестивость'. Ср.:

- filthy: «very evil : morally wrong»;

- vile: «morally despicable or abhorrent»;

- iniquity: «something that is unfair or evil» $(\mathrm{M}-\mathrm{W})$.

Иов осознает всю ничтожность творения перед Богом, о чем также свидетельствуют его риторические вопросы (What is man, that he should be clean? and he which is born of a woman, that he should be righteous?). Анализируемая эмоция, переполняющая праведника благоговением перед Всевышним, имплицируется молчанием (I will lay mine hand upon my mouth). Непосредственное выражение чувств, пишет М.М. Бахтин, оскорбляет благоговение, и «единственно достойное выражение человека перед предметом благоговения - молчание» [Бахтин, 2002, с. 376].

(5) Then said I, Woe is me! for I am undone; because I am a man of unclean lips, and I dwell in the midst of a people of unclean lips: for mine eyes have seen the King, the LORD of hosts (Isaiah, 6: 5).

(6) All nations before him are as nothing; and they are counted to him less than nothing, and vanity (Isaiah, 40: 17).

(7) But we are all as an unclean thing, and all our righteousnesses are as filthy rags; and we all do fade as a leaf; and our iniquities, like the wind, have taken us away. $<\ldots>$. But now, O LORD, thou art our father; we are the clay, and thou our potter; and we all are the work of thy hand (Isaiah, 64: 6).

В микроконтекстах (5), (6), (7) изображается ничтожность великого пророка Исайи. Перед началом служения Бог (ЛЕ the King, the LORD of hosts, him) посещает Своего избранника и наделяет его даром пророчества. Их встреча фиксируется глаголом восприятия seen (mine eyes have seen the King). Святость и величие Творца сообщают пророку эмоцию тварности, репрезентируемую ЛЕ с конкретной (clay) и абстрактной (iniquities, filthy, unclean, vanity, nothing) семантикой. В тексте актуализируются свойственные значениям этих слов семы 'нечестивый', 'пустой', ‘ничтожность' и 'тело'. Ср., например:

- unclean: «morally or spiritually impure»;
- vanity: «something that is vain, empty, or valueless»;

- nothing: «someone or something of no or slight value or size»;

- clay: «the human body as distinguished from the spirit» $(\mathrm{M}-\mathrm{W})$.

После восприятия Бога пророк понимает ничтожность тварного человека. Конвергенция стилистических средств - сравнения (as an unclean thing, as filthy rags, as a leaf, like the wind), метафоры (we are the clay, and thou our potter), эмфатической конструкции с глаголом $d o$, усиленной сравнением (we all do fade as a leaf), - воссоздает тварное чувство Исайи и акцентирует нетварность Бога.

\section{Репрезентация нуминозных эмоций кластера «Mysterium tremendum»}

Благоговение и страх, формирующие эмоциональный кластер «Mysterium tremendum», репрезентируются через: а) обозначение эмоции (dread, fear, terribleness); описание (afraid, tremble); выражение (dreadful, terrible). Cемантика этих языковых единиц подвергается изменениям в библейском тексте. С одной стороны, их узуальная отрицательно-оценочная сема не актуализируется, а с другой - в библейском тексте появляется окказиональная положительно-оценочная сема. Вне контекста «языковая единица теряет диктуемые смыслом текста возможные дополнительные значения и утрачивает семантическую конкретность и эмоииональную нагруженность» [Щирова, 2013, с. 75] (курсив наш. - С. П.). Это наблюдение получает глубокое обоснование при исследовании эмотивной семантики: она всегда является связанной, в результате чего нередко имеют место случаи реверсии оценочного знака у языковых единиц [Шаховский, 2009, c. 155,173$]$.

(8) And said, I beseech thee, O LORD God of heaven, the great and terrible God, that keepeth covenant and mercy for them that love him and observe his commandments. <..> > O Lord, I beseech thee, let now thine ear be attentive to the prayer of thy servant, and to the prayer of thy servants, who desire to fear thy name (Nehemiah, 1: 5, 11).

В приведенном микроконтексте описывается молитва Неемии, набожного израиль- 
тянина, узнавшего о разрушении Иерусалима. Личные местоимения первого и второго лица (I, thee, thy, thine), а также глагол говорения (beseech) маркируют диалог героя с Творцом и сигнализируют о нуминозном страхе персонажа. Он выражается прилагательным terrible и описывается глаголом to fear. О нуминозности страха свидетельствует и семантическая связь эпитета great, изображающего Бога, с прилагательным awesome (Roget, p. 271). Методом многоступенчатого дефиниционного анализа в структуре его значения были выявлены семы 'страх' и ‘благоговение':

- awesome (1 ступень анализа): «causing feelings of awe»;

- awe (2 ступень анализа): «an emotion variously combining dread, veneration, and wonder that is inspired by authority or by the sacred or sublime» (M-W).

Во второй дефиниции фиксируются также актуализируемые в тексте семы 'святой' и 'возвышенный', подтверждающие нуминозность переживаний Неемии. Отрицательная оценочная нагруженность эмотивов terrible и fear нивелируется благодаря их сочетаемости с глаголом desire, в семантике которого актуализируются семы 'желание' и 'интенсивность эмоции' - сp.: «a strong hope or wish» (LDCE), и глаголом love, описывающим положительное чувство, которое испытывает человек по отношению к Богу. Исполненный любви к Всевышнему, Неемия жаждет благоговеть и трепетать перед именем Творца (desire to fear thy name). В библейском тексте имя и личность Бога неразрывно связаны между собой (ББС, с. 576).

(9) The fear of the LORD is clean, enduring for ever: the judgments of the LORD are true and righteous altogether (Psalm, 19: 9).

(10) O taste and see that the LORD is good: blessed is the man that trusteth in him. O fear the LORD, ye his saints: for there is no want to them that fear him (Psalm, 34: 8-9).

(11) The LORD reigneth; let the people tremble: he sitteth between the cherubims; let the earth be moved. The LORD is great in Zion; and he is high above all the people. Let them praise thy great and terrible name; for it is holy (Psalm, 99: 1-3).

(12) Blessed is every one that feareth the LORD; that walketh in his ways. For thou shalt eat the labour of thine hands: happy shalt thou be, and it shall be well with thee (Psalm, 128: 1-4).
В микроконтекстах (9), (10), (11), (12) изображается благоговение и страх Давида перед величием и святостью Творца. Эти эмоции обозначаются существительным fear, описываются глаголами tremble и feareth и выражаются эмоционально-усилительными прилагательными great и terrible. Семы 'страх' и 'интенсивность эмоции', свойственные значениям ЛЕ terrible и tremble, свидетельствуют о религиозной возбужденности Давида. Ср.:

- terrible: "exciting extreme alarm or intense fear»;

- tremble: «to be affected with great fear or anxiety» (M-W).

Отрицательная оценочная нагруженность языковых репрезентантов нуминозного страха нейтрализуется положительной оценкой, которая выражена эпитетами clean и holy, характеризующими чистоту Страха Божия и святость Его имени (The fear of the LORD is clean, thy great and terrible name; for it is holy). Cp.:

- holy: «exalted or worthy of complete devotion as one perfect in goodness and righteousness»;

- clean: «free from moral corruption or sinister connections of any kind» $(\mathrm{M}-\mathrm{W})$.

Страх Божий гарантирует каждому человеку блаженство, счастье и процветание. Стилистическая инверсия (Blessed is every one, happy shalt thou be) позволяет акцентировать эту причинно-следственную связь. Эмоции благоговения, страха, блаженства и счастья, описываемые в приведенных микроконтекстах, диффундируют, а эксплицирующие их ЛЕ great, blessed, feareth, tremble и happy образуют единый эмоционально-оценочный ряд. Особую значимость приобретает призыв бояться Бога в (10): O fear the LORD, ye his saints. Поскольку он обращен к святым (saints), то исключает возможность интерпретировать изображенную эмоцию как ануминозный страх, то есть страх перед наказанием за преступления.

(13) In the fear of the LORD is strong confidence: and his children shall have a place of refuge. The fear of the LORD is a fountain of life, to depart from the snares of death (Proverbs, 14: 26-27).

(14) The fear of the LORD tendeth to life: and he that hath it shall abide satisfied; he shall not be visited with evil (Proverbs, 19: 23). 
В микроконтекстах (13), (14) Соломон, один из ключевых библейских персонажей, размышляет о нуминозном страхе (он обозначен ЛЕ fear). Окказиональная положительная оценка этой эмоции обеспечивается метафорой a fountain of life, уподобляющей Страх Божий источнику жизни. О положительной окказиональной оценке, выраженной лексемой fear, свидетельствуют существительное confidence, обозначающее надежду, и причастие satisfied со значением «удовлетворение». Именно в Страхе Божием человек приобретает уверенность, удовлетворение и безопасность в жизни (place of refuge, depart from the snares of death, he shall not be visited with evil). Эпитет strong, интенсифицирующий сему 'уверенность' в ЛЕ confidence, а также стилистическая инверсия (In the fear of the LORD is strong confidence) обеспечивают важный текстовый смысл - нуминозный страх гарантирует надежность и безопасность в жизни. Кроме того, согласно данным идеографического словаря, ЛЕ confidence семантически коррелирует с ЛЕ courage (Roget, p. 127), которая определяется как «mental or moral strength to venture, persevere, and withstand danger, fear, or difficulty» (M-W). Страх перед Богом сообщает смелость, позволяющую противостоять любому ануминозному страху в жизни. В психологии отмечается, что страх сопровождается чувством неуверенности и незащищенности [Изард, 2011, с. 324], которые, как показывает языковой материал текста Библии, несвойственны нуминозному страху, являющемуся художественной моделью реальных религиозных переживаний.

\section{Репрезентация нуминозных эмоций кластера «Mysterium fascinans»}

Языковая репрезентация эмоционального кластера «Mysterium fascinans» (очарование, удивление, блаженство, счастье, радость) в тексте Библии осуществляется через его: a) обозначение (amazement, gladness, joyfulness); б) описание (happy, blessed, glad, amazed, delighteth, rejoice); в) выражение (wonderfully, marvelous). Эти языковые репрезентанты с узуальной положительной оценкой формируют единый эмоционально-оценочный ряд с языковыми репрезентантами нуми- нозных эмоций кластера «Mysterium tremendum», которые, как было показано выше, наделяются окказиональной положительной оценкой в тексте Библии. Этот вывод коррелирует с наблюдениями В.И. Шаховского относительно закономерностей эмотивного текста, а именно: для данного текста, как правило, не характерна совместность эмотивов с полярными оценочными знаками [Шаховский, 2009 , c. 154].

(15) Be wise now therefore, O ye kings: be instructed, ye judges of the earth. Serve the LORD with fear, and rejoice with trembling (Psalm, 2: 10-11).

(16) Praise ye the LORD. Blessed is the man that feareth the LORD, that delighteth greatly in his commandments (Psalm, 112: 1).

(17) I will praise thee; for I am fearfully and wonderfully made: marvellous are thy works; and that my soul knoweth right well (Psalm, 139: 14).

В приведенных микроконтекстах в молитвенном обращении к Творцу (thee, thy, the $L O R D)$ Давид переживает комплекс нуминозных эмоций, входящих в кластер «Mysterium fascinans». Эти эмоции (радость, очарование, блаженство) описываются глаголами rejoice, delighteth, praise и выражаются эмоционально-усилительным наречием wonderfully и прилагательным marvelous. В библейском тексте в значении этих ЛЕ актуализируются свойственные им семы указанных эмоций ('удовольствие', 'радость', 'удовлетворение', 'восторг’), а также сема 'интенсивность эмоции'. Ср.:

- rejoice: «to feel joy or great delight»;

- delighteth: «a high degree of gratification or pleasure»;

- wonderful(ly): «extremely good»;

- praise: «to express thanks to or love and respect for (God)»;

- marvelous: «extremely good or enjoyable» $(\mathrm{M}-\mathrm{W})$.

Давид очарован могуществом Творца, проявляемым в Его делах (I am fearfully and wonderfully made: marvellous are thy works). ЛЕ rejoice, blessed, wonderfully, marvellous образуют единый эмоционально-оценочный ряд с ЛЕ, репрезентирующими нуминозные эмоции кластера «Mysterium tremendum» (fear, trembling, feareth). Давид призывает служить Господу со страхом и радоваться с трепетом (Serve the LORD with fear, and 
rejoice with trembling). Положительная оценочная направленность ЛЕ fear, trembling, feareth подтверждается включением в описание анализируемых эмоций причастия Blessed, характеризующего блаженство тех, кто имеет страх Божий.

(18) And they departed quickly from the sepulcher with fear and great joy; and did run to bring his disciples word. And as they went to tell his disciples, behold, Jesus met them, saying, All hail. And they came and held him by the feet, and worshipped him (Matthew, 28:8-9).

В микроконтексте (18) описывается нуминозная эмоция ликования жен-мироносиц, узнавших о воскресении Иисуса Христа (Jesus); она описывается предложным словосочетанием with great joy. Интенсивность этой эмоции маркируется ЛЕ great. Воскресение, манифестирующее всемогущество Бога, вселяет в женщин страх и благоговение, на что указывают словосочетание with fear и глагол worshipped. В значении глагола worshipped содержатся семы 'божество' и 'благоговение': «to honor or reverence as a divine being or supernatural power» $(\mathrm{M}-\mathrm{W})$, сигнализирующие о нуминозности переживаний персонажей. Эта диффузность репрезентируемых нуминозных эмоций (страх, благоговение, ликование) отражает онтологию религиозного опыта.

(19) I was in the city of Joppa praying: and in a trance I saw a vision, A certain vessel descend, as it had been a great sheet, let down from heaven by four corners; and it came even to me $<\ldots>$. And I heard a voice saying unto me, Arise, Peter; slay and eat. But I said, Not so, Lord: for nothing common or unclean hath at any time entered into my mouth (Acts, 11: 5).

В микроконтексте (19) описывается видение апостола Петра и его диалог с Богом. Глаголы восприятия (heard, saw), говорения (praying, said, answered), а также адресативы (Lord, Peter) маркируют их беседу. Нуминозная эмоция очарования, обозначаемая ЛЕ trance, семантически коррелирует с ЛЕ spell (Roget, p. 603) и в толковом словаре дефинируется как «a state of enchantment» (M-W). В приведенном определении фиксируется актуализируемая в тексте сема 'очарование'. Бог, разговаривающий с апостолом, изумляет его.
(20) And immediately he rose up before them, and took up that whereon he lay, and departed to his own house, glorifying God. And they were all amazed, and they glorified God, and were filled with fear, saying, We have seen strange things to day (Luke, 5: 25-26).

В этом микроконтексте изображается одно из чудес Христа (исцеление больного), которое изумляет свидетелей чуда. Эта эмоция репрезентируется ЛЕ amazed и glorified. Фиксируемая в словарной дефиниции глагола glorified сема 'восторг' - «to make glorious by bestowing honor, praise, or admiration» (M-W) актуализируется в тексте. Глагол $\operatorname{amaze}(d)$ имеет семантическую связь с глаголом fascinate (Roget, p. 28) и в толковом словаре определяется как «to attract greatly» $(\mathrm{M}-\mathrm{W})$. Однако помимо очарования Христом люди испытывают также трепет перед могуществом Спасителя, на что указывает предложное словосочетание with fear. Эпитет strange, характеризующий деяния Христа (strange things), имеет в своем значении сему 'awe'strange: «exciting wonder or awe» $(\mathrm{M}-\mathrm{W})$. Именно она и актуализируется в тексте. Страх и благоговение переполняют людей. Полисиндетонная связь лексем, репрезентирующих эмоции очарования, восторга и трепета (And they were all amazed, and they glorified God, and were filled with fear), акцентирует нуминозную охваченность творения перед всемогуществом Творца.

\section{Выводы}

Религия, являясь одной из фундаментальных бытийных ориентаций человека, peализуется в религиозном дискурсе. Уникальность данного дискурса состоит в том, что его участником является Бог [Карасик, 2002, c. 221]. Контакт с Творцом вызывает у человека нуминозные эмоции, репрезентируемые языковыми средствами с эмотивной семантикой различного статуса - денотативного, коннотативного, потенциального и наведенного. Языковые репрезентанты исследуемых эмоций характеризуются узуальной / окказиональной положительной оценкой. Анализ микро- и макроконтекстов исследуемого текста свидетельствует об окказиональных смысловых наслоениях в семантике проанализированных языковых единиц. 
Глубинное познание реальности, отличающее XX-XXI вв., реализуется в синтезе научного, философского, художественного и религиозного подходов. В результате холистического взгляда на мир обретается целостное ви́дение человека [Постовалова, 2012, с. 55]. Эмотиологическое исследование нуминозности позволяет углубить научные представления о homo sentiens, переживающего мир не только в горизонтальной (человек - человек), но и вертикальной (человек - Бог) плоскостях своего бытия.

\section{ПРИМЕЧАНИЯ}

${ }^{1}$ В связи с отсутствием в психологии единой трактовки понятий «ощущение», «эмоция» и «чувство» в статье термин «эмоция» используется как родовой, то есть включающий в себя понимание чувства и ощущения.

${ }^{2}$ Безусловно, эмоция тварности не является собственно эмоцией. Она представляет собой интеллектуальную эмоцию, под которой в психологии понимается «специфическое переживание, возникающее у человека в процессе мыслительной деятельности» [Ильин, 2001, с. 190] (ср. номинацию В.И. Шаховского «эмоция-мысль персонажа» [Шаховский, 2010, с. 69]).

${ }^{3}$ Текст цитируется по изданию: King James Bible. URL: https://www.kingjamesbibleonline.org/ (date of access: 20.01.2018).

\section{СПИСОК ЛИТЕРАТУРЫ}

Аверинцев С. С., 2006. Судьба // София-Логос. Словарь : собр. соч. / под ред. Н. П. Аверинцевой и К. Б. Сигова. Київ : Дух і ліра. C. $404-410$.

Бахтин М. М., 2002. Рабочие записи // Собрание сочинений : в 6 т. М. : Русские словари. Языки русской культуры. Т. 6. С. 371-431.

Бобырева Е. В., 2015. Когнитивно-эмоциональное пространство религиозной коммуникации // Вестник Тюменского государственного университета. Гуманитарные исследования. Humanitates T. 1, № 2 (2). C. 51-59.

Бондарко А. В., 1987. Введение. Основания функциональной грамматики // Теория функциональной грамматики. Введение. Аспектуальность. Временная локализованность. Таксис. Л. : Наука. С. 5-39.

Изард К. Э., 2011. Психология эмоций. СПб. : Питер. $461 \mathrm{c}$.
Ильин Е. П., 2001. Эмоции и чувства. СПб. : Питер. $752 \mathrm{c}$.

Карасик В. И., 2002. Языковой круг: личность, концепты, дискурс. Волгоград : Перемена. 477 с.

Касавин И. Т., 1998. Миграция. Креативность. Текст. Проблемы неклассической теории познания. СПб. : РХГИ. 408 с.

Мечковская Н. Б., 1998. Язык и религия. М. : Агентство «ФАИР». $352 \mathrm{c}$.

Отто Р., 2008. Священное. Об иррациональном в идее божественного и его соотношении с рациональным. СПб. : Изд-во Санкт.-Петерб. ун-та. $272 \mathrm{c}$.

Постовалова В. И., 2012. Теолингвистика в современном гуманитарном познании: истоки, основные идеи и направления // Научно-педагогический журнал Восточной Сибири «Magister Dixit». № 4 (12). С. 54-101.

Постовалова В. И., 2014. Религиозные концепты в православном миросозерцании (опыт теолингвистического анализа) // Критика и семиотика. №2. С. 127-148.

Ухтомский А. А., 1996. Интуиция совести: Письма. Записные книжки. Заметки на полях. СПб. : Петерб. писатель. 528 с.

Филимонова О. Е., 2007. Эмоциология текста. Анализ репрезентации эмоций в английском тексте. СПб. : Книжный Дом. 448 с.

Филимонова О. Е., 2016. Репрезентация эмоций в стихотворениях Шела Силверстейна // STUDIA LINGUISTICA. Вып. XXV. Актуальные вопросы языка и текста в современных филологических исследованиях : сб. науч. тр. СПб. : Политехника-сервис. С. 183-189.

Шаховский В. И., 2009. Категоризация эмоций в лексико-семантической системе языка. М. : ЛИБРОКОМ. 208 c.

Шаховский В. И., 2010. Эмоции: Долингвистика, лингвистика, лингвокультурология. М. : ЛИБРОКОМ. $128 \mathrm{c}$

Щирова И. А., 2013. Текст сквозь призму сложного. СПб. : Политехника-сервис. $216 \mathrm{c.}$

Энциклопедия..., 2009. Энциклопедия эпистемологии и философии науки. М. : «Канон ${ }^{+} »$ РООИ «Реабилитация». 1248 с.

\section{ИСТОЧНИКИ И СЛОВАРИ}

ББС - Большой библейский словарь, 2005 / под ред. У. Элуэлла, Ф. Камфорта. СПб. : Библия для всех. 1503 c.

$L D C E$ - Longman Dictionary of Contemporary English. URL: http://www.ldoceonline.com/dictionary (date of access: 15.01.2018).

$M-W-$ Merriam-Webster Dictionary. URL: http://www. merriamwebster.com (date of access: 15.01.2018). 
Roget - Roget's Superthesaurus by Marc McCutcheon, 2003. Cincinnati : Writer's digest books. $667 \mathrm{p}$.

\section{REFERENCES}

Averintsev S.S., 2006. Destiny. Averintseva N.P., Sigov K.B., eds. Collection of works. SofiyaLogos. Glossary. Kiev, Dukh i litera Publ., pp. 404-410.

Bakhtin M.M., 2002. Notes. Collection of works in 6 vols. Vol. 6. Moscow, Russkie slovari Publ.; Yazyki slavyanskoy kultury Publ., pp. 371-431.

Bobyreva E.V., 2015. Cognitive and emotional space of religious communication. Vestnik Tyumenskogo gosudarstvennogo universiteta. Gumanitarnye issledovaniya. Humanitates [Tyumen State University Herald. Humanities Research. Humanitates], vol. 1, no. 2(2), pp. 51-59.

Bondarko A.V., 1987. Introduction. Fundamentals of functional grammar. Teoriya funktsionalnoy grammatiki. Vvedenie. Aspektualnost. Vremennaya lokalizovannost. Taksis. Leningrad, Nauka Publ., pp. 5-39.

Izard K.E., 2011. Psychology of emotions. Saint Petersburg, Piter Publ. 461 p.

Ilyin E.P., 2001. Emotions and feelings. Saint Petersburg, Piter Publ. 752 p.

Karasik V.I., 2002. Language circle: personality, concepts, discourse. Volgograd, Peremena Publ. $477 \mathrm{p}$.

Kasavin I.T., 1998. Migration. Creativity. Text. Problems of non-classical theory of cognition. Saint Petersburg, RHGI Publ. 408 p.

Mechkovskaya N.B., 1998. Language and religion. A manual for students of humanities universities. Moscow, Agentstvo FAIR. 352 p.

Otto R., 2008. The sacred. On the irrational in the idea of the Holy and its correlation with the rational. Saint Petersburg, ANO St. Petersburg university Publ. 272 p.

Postovalova V.I., 2012. Theolinguistics in modern humanities: origins, basic ideas and trends. Nauchno-pedagogicheskiy zhurnal Vostochnoy Sibiri "Magister Dixit» [Scientific and pedagogical journal of Eastern Siberia "Magister Dixit'], no. 4 (12), pp. 54-101.
Postovalova V.I., 2014. Religious concepts in Orthodox Christian Worldview (A theolinguistic analysis). Kritika i semiotika [Critique and semiotics], no. 2, pp. 127-148.

Ukhtomskiy A.A., 1996. The intuition of conscience. Letters. Notes. Notes on the margin. Saint Petersburg, Peterburgskiy pisatel Publ. 528 p.

Filimonova O.E., 2007. The Emotiology of text. The analysis of representing emotions in English text. Saint Petersburg, Knizhnyy Dom Publ. $448 \mathrm{p}$.

Filimonova O.E., 2016. Representation of emotions in Shel Silverstein's poetry. STUDIA LINGUISTICA. Aktualnye voprosy yazyka $i$ teksta $v$ sovremennykh filologicheskikh issledovaniyakh. Sb. nauchnykh trudov [STUDIA LINGUISTICA. Relevant issues of language and text in modern philological studies. Collection of scientific works], no. XXV, pp. 183-189.

Shakhovskiy V.I., 2009. Categorization of emotions in the lexico-semantic system of language. Moscow, LIBROCOM Publ. 208 p.

Shakhovskiy V.I., 2010. Emotions: prelinguistics, linguistics, linguoculturology. Moscow, LIBROCOM Publ. 128 p.

Shchirova I.A., 2013. Text through the prism of complexity. Saint Petersburg, Politehnika-servis Publ. 216 p.

Encyclopedia of epistemology and philosophy of science, 2009. Moscow, 'Kanon+' ROOI 'Reabilitatsihttps://https://ya' Publ. 1248 p.

\section{SOURCES AND DICTIONARIES}

Eluel U., Kamfort F., 2005. Tyndale Bible dictionary. Illinois, Tyndale house Publ. 1503 p.

King James Bible. URL: https://www.kingjamesbibleonline. org/. (accessed 20 January 2018).

Longman Dictionary of Contemporary English. URL: http://www.ldoceonline.com/dictionary. (accessed 15 January 2018).

Merriam-Webster Dictionary. URL: http://www. merriamwebster.com. (accessed 15 January 2018).

Roget's Superthesaurus by Marc McCutcheon. Cincinnati, Writer's digest books, 2003.667 p. 


\section{Information about the Author}

Sergey M. Pashkov, Candidate of Sciences (Philology), Associate Professor, Department of Humanities Education and Pedagogical Technologies, Saint Petersburg State Pedagogical University (Volkhov Branch), Oktyabrskaya naberezhnaya St., 1a, 187403 Volkhov, Russia, s.p.n1980@mail.ru, https://orcid.org/0000-0002-7552-7304

\section{Информация об авторе}

Сергей Михайлович Пашков, кандидат филологических наук, доцент кафедры гуманитарного образования и педагогических технологий, Санкт-Петербургский государственный педагогический университет им. А.И. Герцена (Волховский филиал), ул. Октябрьская наб., 1а, 187403 г. Волхов, Россия, s.p.n1980@mail.ru, https://orcid.org/0000-0002-7552-7304 